\title{
EL TRANSFUGUISMO ELECTORAL. UN DEBATE CONSTITUCIONAL EN MÉXICO
}

\author{
TURNCOAT AND POLITICAL DEFECT. \\ A CONSTITUTIONAL DEBATE IN MEXICO
}

\section{Luis Efrén RÍOS VEGA}

RESUMEN: Este trabajo plantea el debate constitucional del transfuguismo electoral en el sistema presidencial mexicano. En la primera parte se describe el concepto sobre el cual descansa el objeto del problema del transfuguismo electoral, para así diferenciarlo del parlamentario, lo cual encuentra una explicación en la evolución de las diferentes etapas históricas de la movilidad política que ha tenido México desde 1929 a la fecha. En la segunda parte, se realiza una sistematización argumentativa de las diversas cuestiones constitucionales que se pueden discutir en torno al transfuguismo electoral, a partir de los casos que la SCJN y el TEPJF han resuelto en los últimos años. El debate constitucional sigue abierto: existen buenas razones para construir, a partir de una concepción del mandato partidista, una serie de límites razonables a los tránsfugas dentro de la vida interna de los partidos a fin de salvaguardar los principios constitucionales en materia electoral, como lo son el de certeza, transparencia y equidad en el acceso al cargo público representativo.

Palabras clave: transfuguismo, derecho a ser votado, lealtad y disciplina partidista.
ABSTRACT: This research study outlines the constitutional debate of the political desertion of the party's militancy on the presidential system in Mexico. The first part describes the concept in which lies the object of the political desertion of party's militancy problem, to make a distinction between it from Parliamentarian system, which finds its explanation in the evolution of historical stages of the political shifting activity that has been taking place in Mexico since 1929 to this date. In the second part, I systematize several argument issues of constitutional matters that can be discussed around the problem, on the basis of specific cases handled in the $S C J N$ and TEPJF that have been resolved in recent years. The constitutional debate remains open: there are good reasons to build, from a conception of the party's mandate, to establish reasonable limits to disloyal political activity within the internal life of the parties in order to safeguard the constitutional principles on electoral matters, such as legality, transparence and equity.

Descriptors: Disloyal Political, Right to be Voted, Loyalty and Party Discipline. 


\section{SITUACIÓN ACTUAL DE LA DISCUSIÓN}

En México, el transfuguismo político es un concepto jurídicamente reciente. En la práctica política, en cambio, resulta ser una figura clave para entender la transición democrática del país: los tránsfugas, principalmente priístas, han contribuido al cambio político desde las últimas décadas del siglo XX a la fecha. En efecto, durante el régimen presidencial priísta (1929-2000) el transfuguismo no fue un problema: la disciplina, la unidad partidista y la lealtad hacia la línea presidencial funcionaron en gran medida para consolidar la clase política del "partido hegemónico" (Sartori 2000). Al que traicionaba al partido se le castigaba en sus aspiraciones políticas. En la alternancia política, sin embargo, el transfuguismo es parte de la forma de hacer política: cambiarse de partido ofrece la posibilidad de ganar el poder. La deslealtad o la disidencia partidistas comenzaron a ser rentables: presentarse con otras siglas a las elecciones y romper, por ende, con el viejo régimen que los formó, fue para muchos atractivo tanto por el triunfo electoral como por la necesidad de canalizar su oposición. Escenarios y rasgos complejos para el sistema de partidos que contextualizan la alterancia en el poder en los últimos 20 años y que, además, permiten explicar los nuevos problemas que enfrenta la democracia actual: la fragmentación partidista, ideológica y política por el transfuguismo electoral retribuido.

Pues bien, el tema del transfuguismo se traslada hoy a la agenda constitucional. Deja de tener nada más relevancia política para tener impacto en la justicia constitucional electoral. ${ }^{1}$ Los actores políticos le preguntan al juez constitucional: ¿es válido imponer reglas de derecho que limiten la libertad de los transfuguistas? Dicho de otra manera: ¿es razonable o no prohibir el derecho a la participación política por la movilidad partidista? Existen intentos legislativos por regular el tema, lo cual ha genera-

1 Las cuestiones constitucionales se han intensificado en los últimos años. Existe sin duda un alto grado de conflictividad en sede judicial: el eje rector de las discusiones radica principalmente en la defensa de los derechos políticos fundamentales. El país se construye [o destruye] a "golpe de resolución" que va significando las reglas de la convivencia democrática. El Poder Judicial mexicano ha cobrado una nueva dimensión política: es parte del debate en la agenda nacional en la transición política. Véase Vázquez, R., (2007). 
do que el juez electoral mexicano se pronuncie sin tener aún una línea argumentativa clara que defina la libertad política de los tránsfugas. ${ }^{2}$

En algunas legislaciones de entidades federativas (Morelos, Coahuila y Distrito Federal), por ejemplo, se han diseñado como parte de las reglas del juego medidas antitransfuguistas para fortalecer a los partidos y, por ende, mantener a la clase política del gobierno local, principalmente. La finalidad es clara: disminuir los riesgos y problemas de la división partidista que afectan la competencia electoral. En el ámbito del Congreso de la Unión es también un aspecto pendiente de discutir a partir de una propuesta legislativa que tiene como finalidad prohibir la candidatura de una persona que se postula por un partido diferente al que pertenece o haya pertenecido. ${ }^{3}$

En el plano judicial hay algunos antecedentes. Ha sido tratado - el transfuguismo - de manera aislada en sede del Tribunal Electoral del Poder Judicial de la Federación (en adelante TEPJF), a partir de casos concretos: González (2003), Luna (2006) y Albores (2006), los cuales han dado pauta para que el juez electoral examine algunas conductas de deslealtad partidista, movilidad política y participación electoral de los tránsfugas. Por su parte, la Suprema Corte de Justicia de la Nación (en adelante SCJN), se pronunció por primera vez sobre la constitucionalidad de la figura del transfuguismo electoral en el caso Coahuila (2007). En efecto, el 5 de noviembre de 2007 la Corte declaró la invalidez de una norma que impidía al tránsfuga electoral la posibilidad de ser votado por haber sido postulado por un partido diferente al suyo. La legislación electoral de Coahuila reguló como causa de inelegibilidad por razón de deslealtad partidista el transfuguismo electoral: "todo aquel que se postule por un partido al que no pertenece está fuera de la competencia”. Se prohibió, así, el nomadísmo partidista a la hora de buscar la candidatura

2 Por la dinámica del federalismo electoral mexicano no es díficil encontrar otros casos judiciales, legislaciones locales o iniciativas federales que se refieran al tema, distintos a los que se citan en este trabajo. No obstante ello, las referencias aquí utilizadas me parecen suficientes para aproximarnos al debate constitucional del transfuguismo.

3 El diputado Gustavo Cárdenas Monroy (PRI) propone reformar el artículo 41 de la Constitución para establecer que no podrá ser candidato el "ciudadano que provenga de partido diverso al postulante a no ser que evidentemente se haya separado de manera formal y definitiva del partido de origen al menos tres años antes de la fecha de registro para las candidaturas de la elección de que se trate", Cámara de Diputados: LX Legislatura, Gaceta Parlamentaria, México, año IX, núm. 2109, 10 de octubre de 2006. 
de un "cargo público representativo", que es la base del derecho político fundamental de acceder, en condiciones de libertad e igualdad y sin restricciones ni distinciones indebidas, a las funciones y cargos públicos en una democracia representativa (Aguiar de Luque 1984; García Roca 1995, 1999 y 2000; Pulido Quecedo 1992; Martín Núñez 1996; Rallo Lombarte 1997; Salazar 1999).

En este trabajo pretendo analizar el debate de la constitucionalidad del transfuguismo electoral mexicano. El punto de partida es el discurso argumentativo del caso Coahuila (2007), el cual tiene como antecedentes inmediatos los casos González (2003), Luna (2006) y Albores (2006) que constituyen, sin duda, la base sustancial para la discusión del caso Distrito Federal (2008). Este último, además, puede servir de marco para la nueva polémica que puede reelaborar y, en su caso, refinar la interpretación de la SCJN a partir de problemas y escenarios diferentes, tal como lo es el hecho de prohibir o no la libertad del tránsfuga que participa en un proceso de precampaña de un partido diferente al que lo postula. Mi propósito es destacar sobre todo que la cuestión no está cerrada, por el contrario, existe la posibilidad de examinar una nueva línea argumentativa, a propósito de la opinión del TEPJF (SUP-AG-20/2007), en donde el criterio de inconstitucionalidad de la regla en contra de los tránsfugas electorales puede variar dado que se introducen nuevas variables y realidades al problema. ${ }^{4}$ La Corte, por tanto, deberá examinar y construir, con una mayor profundidad y refinamiento, la mejor concepción de las restricciones (aceptables e inaceptables) que se pueden legislar en torno a los límites del derecho a ser electo por razón de la deslealtad y cambio partidista en una elección.

Por tanto, el presente artículo tiene por objeto plantear las diversas cuestiones que desde un plano teórico se pueden desarrollar en torno al tema. Se propone desarrollar una deliberación teórica a partir de los diversos casos concretos y abstractos que de manera preferente construyen el significado del transfuguismo electoral en el marco del derecho fundamental de ser votado. Pues el transfuguismo electoral es una problemática, a mi juicio, que resulta relevante para debatir el tipo de concepción filosófica que pretendamos elaborar en torno a la representación política:

4 El criterio inicial del caso Coahuila (2007) es importante para entender la orientación del discurso judicial en torno a la cuestión de constitucionalidad del transfuguismo electoral, pero no es ni debe ser definitivo. 
si bien es cierto que el debate clásico entre el mandato "libre o dependiente, vinculado o desvinculado" es una discusión de la teoría de la representación política que se refiere al ejercicio del poder (Pitkin 1985; Sartori 1999; Bobbio 2003); aquí me interesa, sin embargo, retomarlo como eje toral para discutir el grado de lealtad o deslealtad política que se debe permitir o prohibir a la hora de luchar por el poder en un sistema presidencial. Pues la polémica del transfuguismo en México se ha dado en el contexto del presidencialismo, preferentemente en cargos de elección por el principio de mayoría relativa y con problemas en especial sobre el acceso al poder (ir por otro partido para ganar el cargo público), diferente a la cuestión del transfuguismo del régimen parlamentario (cambiar de partido para formar gobierno con otros); con lo cual resulta pertinente analizar el tratamiento legal que se le debe dar al tránsfuga electoral como parte de un problema que debilita el sistema de partidos en un régimen presidencial.

Dividiré en dos partes el desarrollo del tema. En la primera trataré brevemente de contextualizar, a partir de nuestra realidad e historia política, el concepto de transfuguismo electoral que es la base de la polémica que nace en el sistema presidencial mexicano, pues la doctrina europea que más ha estudiado este tema en la teoría de la representación política, parte de hechos, hipótesis y problemas diferentes que son necesarios aclarar para entender por qué dentro del régimen mexicano, basado principalmente en las candidaturas de elección popular, el transfuguismo electoral sí es un problema distinto con soluciones problématicas (II y III). En la segunda parte ofreceré un panorama general de las principales cuestiones que se pueden plantear a partir de los casos judiciales y la realidad política, a fin de ir puliendo una concepción de transfuguismo electoral que se debe permitir o, en su caso, prohibir. Trato, así pues, de ir apuntando una agenda de temas y argumentos que se deben trabajar en torno al transfuguismo electoral: aquel que opta por cambiarse de partido para competir por el poder (IV).

\section{TRANSFUGUISMO PRESIDENCIAL VS PARLAMENTARIO. UNA NOTA ACLARATORIA}

El transfuguismo es un tema poco explorado en la doctrina constitucional mexicana. Hay que acudir, por tanto, al estudio comparado. En 
Europa y en algunas partes de América Latina se le llama tránsfuga a quien habiendo ganado el cargo público representativo por medio de la lista de un partido $X$, se cambia al grupo parlamentario del partido $Y$. El tránsfuga parlamentario, por tanto, es aquel que "ocupa una ubicación parlamentaria distinta a la que le correspondería según su adscrición político-electoral" (Navarro Méndez 2000; Tomás Mallén 2002; Soriano 2002). La finalidad de este tipo de tránsfuga no es ir por el cargo de elección popular (porque ya lo tiene), sino por un espacio parlamentario diferente al que lo llevó a la representación política. En consecuencia, el militante que abandona un partido para postularse por otro (transfuguismo electoral), no es necesariamente un tránsfuga en un sistema parlamentario, porque es parte de su libertad política de afiliarse o dejar de pertenecer a un determinado partido y competir por otro.

Empero, el problema del tránsfuga electoral mexicano reside justamente en la persona que cambia de partido para presentarse a las elecciones con otras siglas. Su deslealtad o disidencia partidista es para ir por el cargo, no para formar gobierno una vez electo. Esta modalidad del transfuguismo es diferente y se explica, consecuentemente, en el marco cultural de hacer política a la mexicana: ir por otro partido cuando el suyo no lo presenta a las elecciones, sea porque se le considere un demócrata ejemplar o un oportunista inmoral, o las dos cosas al mismo tiempo, constituye en la actualidad una práctica común del juego político mexicano. La experiencia en el sistema electoral mexicano revela, en efecto, que en los últimos años la lucha por el poder tiene mayores enfrentamientos entre los aspirantes de un mismo partido, que hacia los de afuera. Es la selección interna del partido la que puede llegar a determinar el resultado final en una elección; el de ganar o perder el poder. Es útil, por tanto, encontrar los criterios más aceptables para que todos los partidos tengan una fórmula correcta que permita seleccionar con certeza y objetividad a sus liderazgos políticos bajo principios de lealtad y convicción partidista para no defraudar a su base electoral y a sus propios militantes que se ven desplazados por los oportunistas.

Efectivamente, los conflictos internos generan divisiones, traiciones y movilidad política que al final terminan por debilitar la preferencia electoral de un partido. 5 El PRD, por ejemplo, nació fundamentalmente con

5 En la pasada elección federal, el PRI fue el que presentó una mayor conflictividad en la elección de los candidatos al Congreso de la Unión. En primer lugar, el TEPJF en el 
liderazgos que pertenecían al PRI y que, además, rompieron con él en una etapa de la transición política del país. Pero lo cierto es que los problemas de transfuguismo que se pretenden regular en México, son muy diferentes a los que ordinariamente se regulan y preocupan en el sistema parlamentario. No se trata de sancionar a los legisladores que cambian de camisa partidista en el congreso a la hora de tomar decisiones o formar repartos de gobierno por razones retribuidas ilegalmente, sino la discusión está en si es válido o no prohibir que los militantes de un partido participen políticamente como candidatos de otros partidos rivales por razones igualmente retribuidas, a fin de evitar el bandolerismo y oportunismo electoral. Ese es el problema. ¿Y por qué? La práctica nos dice que ese tipo de transfuguismo sí afecta el nivel competitivo del partido: los cuadros tránsfugas hacen perder o ganar, pero ¿ello es suficiente para prohibir esta conducta?

Esta cuestión mexicana, en consecuencia, resulta distinta al transfuguismo parlamentario en donde el representante elegido cambia de grupo parlamentario para hacer gobierno con el que tiene el poder a cambio de ventajas políticas. Así, en el transfuguismo electoral-presidencial se busca sancionar el hecho como causa de inelegibilidad: "si te cambias de partido, no puedes participar", mientras que en el régimen parlamentario tiende a sancionarse al tránsfuga con la pérdida de su cargo, lo cual contradice en cierta medida el mandato libre de los parlamentarios. ${ }^{6}$ En cam-

caso Ruibal y otros (2006) anuló la regla de la cúpula que pretendía validar las fórmulas de diputados y senadores por medio de un órgano con un nivel de representación de tercer nivel (Comisión Política Permanente), quedando al final un órgano más representativo por razón del número de integrantes como lo es el Consejo Político Nacional. Luego fue pública la polémica que se dio al momento de llevar a cabo la validación de las candidaturas en el Consejo Político Nacional, lo que, incluso, hizo suspender la sesión por la falta de acuerdo. Finalmente, se plantearon diversos casos concretos por la vía judicial que reclamaban la pretensión de ser escogidos bajo la regla del perfil idóneo. El PRI, al final de la elección de 2006, terminó por ser el partido que más posiciones y cargos de poder perdió con relación al PRD y PAN que, dicho sea de paso, sí sumaron a su favor a los tránsfugas prí́stas.

6 En España, por ejemplo, el Tribunal Constitucional basándose en la concepción clásica de la prohibición del mandato imperativo de los representantes, tiene una línea jurisprudencial consolidada de declarar inconstitucional las normas que sancionan a los tránsfugas con la pérdida de su cargo público representativo, ya que que los elegidos son los titulares del cargo como derecho fundamental (STC: 5/1983, 10/1983, 16/1983, 20/1983, 28/1983, 29/1983, 30/1983 y 28/1984), aunque existe una nueva orientación ju- 
bio, este es el problema que se pretende regular en México: prohibir la libertad de postularse por un partido diferente al que pertenece o perteneció durante cierto tiempo. En el debate del transfuguismo parlamentario se parte de la idea, no por ello discutible, de que el representante le debe el cargo público representativo al sistema de partidos por las listas cerradas y bloqueadas: los partidos son los que obtienen los votos porque son los que hacen las campañas, ergo, los votos pertenecen más a aquéllos que a los elegidos (García Murillo 1996, 70), aunque por supuesto la titularidad del cargo es del elegido y no del partido (Tomás Mallén 2002, 81 y ss.; García Roca, 2000, 21), razón por la cual se justifica el transfuguismo electoral en el discurso jurisprudencial español. Por el contrario, en el transfuguismo mexicano la mayoría de los cargos de elección popular (presidente-gobernadores-municípes; diputados-senadores), surgen de la competencia por el voto y, por ende, los problemas de traición se presentan a la hora de seleccionar las candidaturas de mayoría relativa. Los votos sí pueden ser individualmente considerados para cada candidato que gana en cada distrito electoral, pero es el partido el que tiene la titularidad para postular candidatos.

Estos rasgos y puntos de partida diferentes explican el tratamiento distinto que se le debe dar a la deslealtad electoral-presidencial (ir por los votos para ganar el cargo), frente a la parlamentaria (ir por los votos para gobernar en el cargo electo). Una y otra se dan en momentos y razones distintas. Los problemas en ambos sistemas deben leerse pues de manera diferente pero ante todo también en forma complementaria. Pues si bien el concepto que se tome como base en un determinado régimen político, no debe ser necesariamente el mismo para examinar las cuestiones que se presentan en otro, ya que esto es lo que sucede con el transfuguismo del régimen parlamentario (que nace en una determinada institución, cultura política y escenarios diversos), a diferencia del transfuguismo electoral que se da en nuestro país dentro de un contexto presidencial. También es cierto que al aplicar un método contextual de pluralismo político y de

dicial hacia la representación partidaria, al tomar en cuenta que la adscripción política del representante tiene relevancia jurídica y no solo política, asi como el hecho de que los votos para elegir las listas presentadas por los partidos no pueden ser considerados a favor de candidatos singularmente considerados porque todos tienen la misma representación, e incluso la vinculación de los representantes al voto popular porque le deben lealtad a los electores que los han elegido para orientar su actuación pública en un sentido determinado ( $c f r$. Tomás, Mallén, 2002, 111 y ss.). 
historia para explicar estos fenómenos en cada lugar, los argumentos de validez desde una perspectiva más filosófica y jurídica sí puedan servir para el debate constitucional en uno u otro sistema político.

\section{LA EVOLUCIÓN DEL TRANSFUGUISMO ELECTORAL-PRESIDENCIAL}

En otro trabajo ${ }^{7}$ trataba de explicar cuatro etapas claramente diferencias entre sí que expresan las diferentes formas en que la política mexicana, desde la etapa posconstitucional a la fecha (1929-2008) ha experimentado el transfuguismo desde mi perspectiva histórica. Decía que había que entender el cómo en la política mexicana se ha iniciado de una total ausencia de transfuguismo por el régimen priista, pasando luego por ser clave para el cambio político, hasta llegar, finalmente, a ser una práctica que comienza a ser retribuida y cuestionada en un sistema de partidos competitivo.

Las etapas que reseñaba eran las siguientes:

1. La fidelidad y disciplina con el partido hegemónico (1929-1988).

2. El rompimiento a la disciplina del régimen presidencial (1988-2000).

3. El oportunismo y el bandolerismo político (2000-2006).

4. La construcción de una partidocracia competitiva (2006-2008).

No me interesa repetir nuevamente la narración histórica de esta práctica en el contexto del sistema presidencial mexicano. La idea central del citado artículo la recojo nada más aquí. En efecto, durante los 72 años del régimen priista el transfuguismo no fue problema; al contrario, la lealtad, unidad y disciplina al partido único en el poder, era la base para articular el régimen presidencial. La clase política no funcionaba en el ejercicio de la libertad política de disentir o contradecir al presidente; luego, el encontrar a un tránsfuga priista con éxito político era casi imposible. ${ }^{8}$ Posteriormente, con el inicio de la transición política se puso en

7 Ríos, L. E., "El transfuguismo electoral en el sistema presidencial mexicano", (pendiente de publicarse en Justicia Electoral, Revista del TEPJF, México, tercera época, núm. 3, 2008.

8 La unidad en torno a la línea oficial era lo más sagrado. Es principio y acción de la cohesión del poder del PRI que los hacía más fuertes. La disciplina partidista implica- 
peligro la unidad del PRI: los tránsfugas comenzaron ha aparecer porque las reglas del juego eliminaron las sanciones prohibitivas inflingidas por la fórmula hegemónica a las escisiones y las rupturas con el partido; con lo cual romper con el PRI es un riesgo calculado que puede traer como consecuencia el ganar el poder. El transfuguismo es clave para la alternancia en el poder. La fundación del PRD se hace principalmente por tránsfugas priístas que reclaman un nuevo régimen político, diferente al que ellos mismos conformaron, participaron y en el cual vivieron, pero que dejó de servir para tutelar sus legítimas aspiraciones por el poder en un régimen más democrático: libre y competitivo. Incluso, el ser tránsfuga en esta época resulta bien visto, tiene buena prensa en medios libres, porque se parte de la idea que la persona que abandona el PRI y se cambia al PRD está en contra del régimen prísta que se quiere erradicar: romper con el antiguo régimen autoritario. El transfuguismo se convierte en una de las causas que permitieron el inicio del cambio democrático en el país. Pero una vez consolidada la alternancia política en la medida en que cualquier partido puede ganar las elecciones, el transfuguismo resulta ser ahora la estrategia política rentable: se gana el poder por el divisionismo partidista. Ser tránsfuga ya no se castiga como en el régimen priísta, sino que se premia en muchas ocasiones con la posibilidad de llegar al poder a cambio de ser desleal. El transfuguismo empieza a tener mala prensa por los excesos e incongruencias. Cada candidatura comienza a estar sujeta al cálculo de irse o no del partido, de buscar o no otros colores partidistas, o bien, de vender o no el capital político que se tiene en un determinado partido para jugar en contra de los intereses partidistas para que otro se beneficie: dividir a su partido para que otro gane. Las candidaturas en el peor de los casos se comienzan a vender y los tránsfugas, por ende, obtienen en forma retribuida un beneficio ilegal a consecuencia de su deslealtad partidista. Finalmente, llegamos hoy a los problemas que se dan en la vida interna de un partido, pues en la medida en que se diseñan, negocian e instrumentan las convocatorias para elegir a los candidatos, se abre el escenario de las divisiones, traiciones y transfugismo retribuido que al final terminan por debilitar a un partido y desprestigiar aún más a la política.

ba la regla de actuar. No se recompensa la libertad de disentir, sino se castiga. Nadie, por tanto, se atrevía a ser tránsfuga. El costo era muy elevado: el ostracismo político. 
Por tanto, el transfugismo político en México se erradica durante casi todo el siglo XX por el autoritarismo de un grupo en el poder que sabía premiar la lealtad y castigar la indisciplina. Pero llegó un momento en que se hizo insostenible para el régimen operar con la línea presidencial, de tal manera que la disidencia se comienza a mostrar para dar cabida a los primeros tránsfugistas que ven en ella una opción democrática para promover el cambio político, pero ante todo la posibilidad real de obtener el poder por la vía de la oposición. Y por ende: como el sistema ahora se ha hecho más competitivo, la traición, la indisciplina o el disentir partidista comienzan a ser recompensados, lo cual viene a desquebrajar la unidad partidista, debilitar su ideología, desplazar indebidamente a militantes y, por ello, defraudar a la base electoral de un partido.

\section{LAS CUESTIONES DEL TRANSFUGUISMO}

Hablar del transfuguismo en política significa discutir uno de los aspectos más problemáticos de la representación política que la ponen en jaque (Tomás Mallén 2002, 23). Lo es por una sencilla razón: el hacer política conlleva el juego de las traiciones y lealtades; ergo, el problema del tratamiento legal del transfuguismo en cualquier caso enfrenta un círculo que lo atrapa: la traición es considerada un acto fundacional de la política (liberal) que denota flexibilidad, adaptabilidad y antidogmatismo, atributos necesarios para que el político mantenga los cimientos de una sociedad. El tránsfuga, por tanto, puede guiarse por su pragmatismo y la convicción de la necesaria defensa de sus derechos individuales junto con el loable propósito de mantener intactos sus valores democráticos, con lo cual el romper con quienes le proporcionaron los medios para su elección (dogmáticos y tiránicos ellos), y representar la opción e intereses de quienes son su base electoral, puede llegar a ser una conducta no sólo lícita sino moralmente aceptable en un régimen plural (Renui i Vilamala 1996, 265 y ss.). Por tanto: si el transfuguismo es ante todo traicionar y gobernar es traicionar, luego ¿qué tiene de malo ello?, si al final de cuentas es parte de la política basada en las libertades y derechos fundamantales que garantiza una democracia. ${ }^{9}$

9 Es el laberinto del transfuguismo: la democracia liberal lo ampara porque así se ha construido con democrátas que rompieron con el antiguo régimen (Rubio Llorente 1993), pero el exceso inmoral, el transfuguismo retribuido (Rodríguez Ramos 1994, 439 
El problema es que uno de los costos relevantes del mandato representativo como libre y no vinculado, sin duda, es la práctica de representantes indeseables que transitan de una formación política a otra, movidos por fines socialmente injustificables (García Roca 2000, 28). Es un tema que recorre toda la historia de la representación política a partir del debate clásico que nos enseña la historia del "gobierno representativo" (Manin 1998). La cuestión es saber si los representantes son libres en el ejercicio de su cargo popular. Si deben ser libres, ergo, no tiene razón alguna limitar a los tránsfugas: el traicionar es parte de la libertad de disentir, la cual es necesaria en una democracia; pero si el mandato de los representantes debe ser en parte vinculado a los electores o al partido, se plantea, entonces sí, la necesidad de regular los límites a la libertad del transfuguista para tutelar valores democráticos: lealtad, compromiso con el voto popular, fortalecer la unidad partidista e ideológica, etcétera.

Ahora bien. ¿A quién consideramos tránsfuga? En sentido gramatical es aquella persona que huye de una parte a otra; esto es, el tránsfuga político en sentido lato será aquel que pasa de un partido a otro, independientemente de las causas, el móvil y las circunstancias. Esa es la raíz lingüística del sujeto calificado como tránsfuga: persona que cambia de partido o ideología. Empero, no toda persona que cambia en cualquier circunstancia debe ser tenida como tal. Es necesario tener un concepto susceptible de ser analizado bajo una perspectiva jurídico-política (Tomás Mallén 2002, 33). Hemos partido nosotros de una base conceptual de transfuguismo electoral diferente al parlamentario dado el contexto histórico-político en México. Nuestro punto de partida es reformular la pregunta del transfuguismo en el sistema mexicano: ¿si para la democracia presidencial importa el garantizar políticos leales a su partido y base electoral, no sólo a la hora de legislar y controlar al Ejecutivo, sino también desde el momento de ir por el voto popular en los procesos electorales? Dicho de otra manera: ¿es válido una regla antitranfuguista para limitar a la clase política de un sistema presidencial?, ¿se puede justificar una concepción del mandato partidista para tutelar la lealtad a los partidos y a sus militantes y simpatizantes?, ¿el mandato partidista tendría

y ss.), podría ser repudiado por el republicanismo de la virtud cívica: una cosa es que se rompa con el gobierno autoritario, y otra muy distinta, que se pretenda defraudar al gobierno democrático con el bandolerismo político. 
que ser imperativo o debería liberar a sus militantes a la hora de ir por las candidaturas?

Me interesa discutir el tema a partir de la cuestión constitucional que se analiza en sede judicial y en el marco del derecho fundamental a ser votado. La SCJN ha dicho en el caso Coahuila (2007) que no es válido establecer en la ley como requisito para desempeñar un cargo de elección popular, el que se exija el no haber sido integrante de un partido político distinto al que lo postula cuando menos dos años antes de la fecha de registro de candidatos de elección de que se trata. Es decir: el transfuguismo así regulado es inconstitucional porque afecta el contenido esencial del derecho a ser votado. El objeto de la norma coahuilense era claro: impedir la participación del tránsfuga partidista. No podrían presentarse a las elecciones — predicaba la regla invalidada por la Corte- las personas que hayan sido integrantes de un partido político distinto al que lo postula. ${ }^{10}$ Esta regla, por tanto, prohibía los cambios de colores partidistas a la hora de competir por una candidatura, bajo la pena de que al hacerlo no se podría ser seleccionado por otro partido. La razón de la regla antitránsfuga se explica por la idea de tutelar la lealtad partidista y evitar, por ende, el divisionismo que pone en riesgo una probable victoria electoral de un partido que se ve afectado por la traición de sus integrantes: se promueve pues el castigo a los desleales que cambian de partido para poder ganar un cargo representativo. Luego entonces, resulta relevante deliberar ¿si es válido o no prohibir la libertad política del sujeto que, al ser integrante de un partido, resulta que es postulado por otro? Dicho de otra forma: ¿es válido cambiar de partido para ir por el poder?, o más bien, ¿se debe prohibir en la democracia la traición política en la lucha por los cargos públicos representativos?

Estas son algunas cuestiones que trataré de apuntar aquí como parte del inicio del debate constitucional a partir de siete cuestiones que me parecen relevantes y que, por tanto, paso a describir por separado.

10 El artículo 15, fracción IX, de la Ley de Instituciones Políticas y Procedimientos Electorales del Estado de Coahuila de Zaragoza, establecía que para desempeñar un cargo de elección popular se deberán cubrir, entre otros requisitos, el no haber sido integrante, en los términos de los estatutos correspondientes, de un partido político distinto al que lo postula cuando menos dos años antes de la fecha de registro de candidatos de la elección de que se trate. En el ámbito local, la reforma se bautizó en la prensa como ley antichaquetera. 


\section{La cuestión de las calidades para ser votado}

El punto de partida del debate constitucional arranca con la concepción que tengamos de las "calidades" que la Constitución mexicana exije para poder ser votado. En efecto, en el caso Coahuila (2007) la SCJN hizo una interpretación sobre qué debe de entenderse por calidades para ser elegible. La Corte responde: son las cualidades o perfil de una persona que vaya a ser nombrada en el cargo tales como: capacidad, aptitudes, preparación profesional, edad y demás circunstancias, que pongan en relieve el perfil idóneo para desempeñar con eficiencia y eficacia el empleo o comisión que se le asigne. Esto es: calidad para ser votado significa, según la Corte, la circunstancia inherente a la persona misma que pretenda ocupar un cargo de elección popular, con lo que evidentemente excluye otro tipo de atributos o circunstancias que no sean esenciales o intrínsecas al sujeto en cuestión. Luego, la Corte razona: la pertenencia a un partido político distinto de aquel que postule a un candidato a un puesto de elección popular, no puede considerarse como una calidad necesaria para ejercer un cargo de esa naturaleza, dado que haber formado parte de un partido político no es un atributo intrínseco relativo a la persona.

El test de la calidad para ser votado puede sintetizar la fórmula siguiente:

P1. Calidad para ser votado es igual a las circunstancias inherentes a la persona que pretenda ocupar un cargo de elección popular.

$P 2$. Pertenecer a un partido político distinto al que lo postula para acceder a un cargo de elección popular, no es una circunstancia inherente a la persona.

$C$. Pertenecer a un partido político distinto al que lo postula no es una calidad para ser votado.

El argumento de la SCJN me parece insuficiente. No nos dice qué entiende por circunstancia inherente a la persona ni tampoco por qué pertenecer a otro partido no es una calidad de ese tipo, pero además el dato que toma en algunos de sus considerandos como base para examinar la constitucionalidad de la norma no debe ser "el no haber pertenecido a un partido político distinto al que lo postula", sino más bien el ser postulado por un partido diferente al que pertenecía. Pues si el problema es la no 
pertenencia a un determinado partido, entonces no estamos ante un caso de transfuguismo sino de falta de militancia necesaria para acceder al cargo. Fuera de este error, me parece que lo que la SCJN quizó explicar es que el prohibir a una persona postularse a una candidatura por un partido distinto al que pertenece o haya pertenecido, no es un atributo esencial de la misma.

Este error viene a cuento porque tengo la impresión de que la Corte lo que debío hacer, en primer lugar, era una distinción: entre las calidades que se pueden exigir para ser votado y las otras calidades que se establecen para no poder serlo. Esta diferencia es básica, porque el enunciado legal que sancionaba el transfuguismo tiene por objeto establecer una calidad para prohibir el ser votado. De ahí su error argumentativo: debe examinar a partir de lo que constitucionalmente se puede prohibir y no de lo que se puede permitir en torno a las calidades de los elegibles. Por ejemplo, no es lo mismo analizar si es una calidad aceptable el tener que ser licenciado en dereho para ser votado como legislador, que el prohibir ese cargo a todo aquel que haya sido condenado por un delito doloso. Los planos son diferentes. En un caso se exige algo para ser y en el otro se impone algo para no poder ser. En el primero se examina si lo que se pide es razonable conforme a la libertad política porque el ciudadano lo puede cumplir libremente para ejercer el cargo; en el segundo, por el contrario, se califica si el hecho motivo de la prohibición es razonable para evitar que un ciudadano, que puede cumplir las calidades exigidas normalmente para ser votado, no puede serlo porque es válido limitarle su acceso por una calidad que califica como prohibición. Claro está que en ambos casos las calidades que constitucionalmente sean válidas deben de partir de una concepción integral que permita analizar tanto las permisiones como las prohibiciones del derecho de ser votado. Pero es importante tener en cuenta esta primera aclaración.

No obstante ello, me interesa más bien analizar si con base en la concepción de las calidades que defiende la Corte se puede resolver este problema. En efecto, me parece correcto que la SCJN se pregunte sobre la categoría de las calidades para ser votado y con base en un significado conceptual determine si la calidad en cuestión es válida o no. Empero, el discurso argumentativo de la Corte fue muy débil. Es más completo, a mi juicio, el debate que se dio en el caso Hernández y otros (2004) en el que, a partir de las diferentes posiciones del TEPJF, se pueden desarro- 
llar las concepciones impersonal y personal de las "calidades de ser electo" como contenido esencial del derecho fundamental a acceder al cargo público representativo.

Pues bien, se debe partir de la base que la categoría de la «calidad de poder ser votado» es la que configura el contenido esencial del derecho fundamental a ser electo. Los ciudadanos pueden estar excluidos de la participación política sobre la base de la idoneidad: la incapacidad que se fija por la edad mínima y la capacidad de obrar, pero también existen personas capaces que están excluidas de la libertad de ser votados por diversas razones constitucionales (conducta delictiva, laicidad, no-reelección, etcétera), o porque no reúnen los requisitos para ser electos (nacionalidad, residencia, etcétera.). Existen, pues, "calidades" constitucionalizadas para no ser votado (el delincuente, el ministro de culto o el presidente que ha ejercido el cargo, respectivamente), pero también la ley puede desarrollar otras diferentes (positivas o negativas) para regular la posibilidad de la ciudadanía de ser elegida en el marco de la sociedad democrática. Luego la cuestión radica en saber: ¿cuál es la concepción aceptable de la "calidad ciudadana para ser votado"? Pues dependiendo de ella se determina el núcleo central de este derecho y se estará, por tanto, en posibilidades de determinar si el transfuguismo puede ser validamente una cuestión de inelegibilidad en el derecho a ser votado. Este ejercicio debe ser previo a todo análisis constitucional de los requisitos para ser electo, pues si hay una calidad que no forma parte del núcleo central, no tendría caso alguno revisar si es o no razonable o proporcional el requisito exigido por la ley, en tanto que una vez que se parte de la idea que es una calidad aceptable con el contenido esencial del derecho a ser electo, se puede evaluar luego si ésta es racional, igualitaria o proporcional a los fines constitucionales. Veamos pues las diferentes alternativas conceptuales.

\section{A. La "concepción impersonal de las calidades"}

La primera solución implica una concepción impersonal de las calidades que se pueden exigir para ser votado, pero que tengan relación con el cargo popular. En efecto: las "calidades" son cualquier requisito, modalidad, circunstancias y/o condiciones que se requieren para un cargo de elección popular. La pertenencia de la calidad del cargo es independiente de la voluntad personal: puede ser una circunstancia ajena a su libertad, 
pero propia del cargo. Por tanto: las calidades se valoran en función de la idoneidad en el cargo y no de la persona, siempre que no impliquen una discriminación injusta.

Esta fue la posición mayoritaria en el caso Hernández y otros (2004), en el cual el TEPJF consideró como válido el requisito necesario para ocupar el cargo, el de haber sido registrado previamente, ante la autoridad electoral, como candidato por un partido político. Este es un claro ejemplo de la impersonalidad que tiene la calidad de poder ser votado: ser postulado por un partido no es una circunstancia personal, porque la voluntad de un partido es diferente a la voluntad de un elegible. Es la concepción impersonal de las calidades, que se sustenta en las razones siguientes:

1) La interpretación gramatical del término calidad $y$ otros similares ${ }^{11}$ implica que si bien una de las acepciones es la propiedad inherente a una cosa, la misma debe descartarse, en primer lugar, porque las "calidades" hacen referencia a un ciudadano (esto es, una persona, no una cosa), y a "cargos de elección popular"; en segundo lugar, porque el apreciar a una persona como igual, mejor o peor que las restantes de su especie no puede predicarse de una persona, ya que resultaría inadmisible y violatoria de los derechos humanos (en particular, del derecho de igualdad) cualquier pretensión de que, por supuestas propiedades o calidades inherentes o naturales, una persona se estimara mejor o peor que otra. En cambio, la "calidad para un cargo popular" sí resulta aplicable a la acepción relativa al "estado de una persona, su naturaleza, su edad y demás circunstancias y condiciones que se requieren para un cargo o dignidad". Esta acepción se relaciona con la circunstancia, que es algo distinto a la sustancia o esencia, toda vez que se refiere a un accidente de tiempo, modo, lugar, etcétera, que está unido a la sustancia de algún hecho o di-

11 Según el Diccionario de la Lengua Española el término calidad es la "propiedad o conjunto de propiedades inherentes a una cosa, que permiten apreciarla como igual, mejor o peor que las restantes de su especie: esta tela es de calidad inferior a otra". Pero también significa el estado de una persona, su naturaleza, su edad y demás circunstancias y condiciones que se requieren para un cargo o dignidad. La circunstancia es "accidente de tiempo, lugar, modo, etcétera, que está unido a la sustancia de algún hecho o dicho. Calidad o requisito. Conjunto de lo que está en torno a uno. El requisito es la "circunstancia o condición necesaria para una cosa". La condición es el "estado, situación especial en que se halla una persona". El término necesaria es lo que "es preciso que intervenga para la validación de un contrato, acto o derecho". 
cho y, por tanto, no es consustancial sino tiene un carácter contingente, razón por la cual esta concepción estima que las calidades, circunstancias o condiciones que puede establecer el legislador para el ejercicio del derecho político-electoral de ser votado, no necesariamente deben estar circunscritas a la naturaleza, esencia o sustancia de un ciudadano. Lo anterior se relaciona si atiende al otro sentido del término circunstancia, que es el de calidad o requisito, en tanto que requisito es la circunstancia o condición necesaria para una cosa. E igualmente condición necesaria tiene una connotación jurídica que es la que debe intervenir para que un acto o derecho sea válido.

2) Las "calidades" que establezca la ley para ser votado no pueden establecerse de manera arbitraria o caprichosa por la autoridad legislativa ordinaria, ya que, en forma alguna, implica que esté autorizado para establecer calidades, requisitos, circunstancias, condiciones o modalidades arbitrarios, ilógicos o no razonables que impidan o hagan nugatorio (fáctica o jurídicamente), el ejercicio de dicho derecho, ya sea porque su cumplimiento sea imposible o implique la violación de alguna disposición constitucional, pues la ley no puede ser abusiva, arbitraria, caprichosa o excesiva. Es decir: está prohibido establecer calidades, condiciones, requisitos o circunstancias que sean absurdos, inútiles, de imposible realización o que, en conclusión, hagan nugatorio el ejercicio del derecho de que se trata; sino que toda "calidad para ser votado" debe servir para dar eficacia a su contenido y posibilitar su ejercicio, haciéndolo compatible con el goce y puesta en práctica de otros derechos, o bien, para preservar otros principios, valores o bases constitucionales que puedan ser amenazados con una concepción irrestricta, ilimitada, incondicionada o absoluta de ese derecho.

Bajo esta concepción impersonal de las calidades para ser votado, la opinión mayoritaria del TEPJF justificó como válido el requisito de ser registrado como candidato necesariamente por un determinado partido político.

\section{B. La "concepción personal de las calidades"}

Una alternativa diferente es la que resulta del voto particular de los magistrados Castillo, Reyes y De la Peza, en el mismo caso Hernández y otros (2004). En él se apela a una "concepción personal de las cualidades o calidades" de las personas que se pueden exigir para poder ser electo, 
tal como lo sugiere la SCJN en el caso Coahuila (2007). Pues las calidades para ser votado sólo pueden relacionarse a las circunstancias inherentes a la persona que pretenda ocupar un cargo de elección popular. Las calidades, por tanto, deben estar integradas al ciudadano mismo y no derivar de elementos o requisitos para cuya formación deba intervenir la posición, voluntad, decisión y otras circunstancias, de personas o entidades ajenas al ciudadano, porque entonces ya no quedaría en el ámbito de éste, mediante el ejercicio de sus demás libertades, la adquisición de esas calidades, sino que se haría depender de la acción y voluntad de terceros. Esta tesis sintetiza las tesis siguientes de la mínoría del TEPJF:

a) Las calidades o cualidades no pueden ser para que sólo un selecto número de ciudadanos pueda reunirlas, con lo cual, evidentemente, se apartaría del principio democrático de la igualdad, pues el acceso al poder sería sólo para una elite.

b) Esas calidades o cualidades deben ser las suficientes y razonables para que los candidatos que obtengan los cargos o puestos de elección popular, puedan ejercerlos eficazmente.

c) El significado natural de calidad, aplicado a una persona, debe entenderse como la propiedad o conjunto de propiedades inherentes a ésta, que permiten compararla o apreciarla en relación con las demás.

d) La voz inherente significa "lo que por su naturaleza está de tal manera unido a otra cosa, que no se puede separar de ella". Luego, lo que define la calidad de una persona son los aspectos propios y esenciales de ésta.

e) Las condiciones que se deben fijar deben ser supuestos de la persona, de por sí, y no por imposición de otros, por estar referidos a la personalidad del individuo en cuanto a sus características internas, sin depender de cuestiones ajenas a éste.

f) Las calidades son los requisitos de elegibilidad, los cuales se refieren a circunstancias que se exigen de una persona como tal, para ocupar algún cargo de elección popular, como es su edad, tiempo de residencia, origen, la vigencia de sus derechos político-electorales, la independencia de criterios y de intereses, etcétera.

g) Una extensión mayor al concepto de calidades para ser votado podría exigir como válidas las posiciones materiales o económicas, sociales, de linaje, tenencia de títulos profesionales de altos grados de estudios 
universitarios, etcétera, lo cual evidentemente pugnaría con el espíritu democrático.

h) Las calidades o condiciones que se pudieran exigir a los ciudadanos, para el ejercicio del derecho a ser votado, son los inherentes a su persona, como su edad o capacidad mental, de modo que se asegure la igualdad de oportunidades a todos los ciudadanos para que tengan acceso a los cargos de elección popular. ${ }^{12}$

Con base en la concepción personal de las calidades la Corte en el caso Coahuila (2007) llega a la conclusión de que la pertenencia a un partido político se considera una calidad inaceptable para acceder a un cargo de elección popular, pues: el formar parte de un partido no es un atributo que resulte intrínsecamente relativo al sujeto en cuestión, por lo que no puede entrar en la categoría de calidades requeridas por la Constitución.

\section{C. ¿Hacia una "concepción mixta de las calidades”?}

La concepción personal de las calidades es el punto de partida para construir una concepción aceptable en el ámbito de la democracia constitucional basada en la libertad e igualdad, pero con algunos matices de impersonalidad que son necesarios reconocer y ponderar. En efecto, el significado única y exclusivamente impersonal de las cualidades o calidades que se pueden exigir para que los ciudadanos pueden ser elegibles, tiene como defecto el desnaturalizar la única exigencia ética que se puede reivindicar a la hora de determinar las cuestiones de elegibilidad y de inelegibilidad: la libertad e igualdad de las personas. Justamente, por ser agentes morales, con la misma capacidad moral, se justifica la razón de la democracia para imponer calidades para ser votados. De lo contrario, resultaría absurdo exigirle cualidades y calidades para ser votado que no son fruto de la libertad e igualdad de cada quien. Se eligen personas, no cosas. No se puede construir el contenido esencial del derecho a ser electo por afuera y en contra de la libertad e igualdad de las personas que tienen el estatus de la ciudadanía. Si nos preguntamos quién puede ser electo, es porque valoramos que sólo podemos exigirles requisitos que

12 Cfr. Organización de las Naciones Unidas, "Interpretación del artículo 25 del Pacto Internacional de Derechos Civiles y Políticos", aprobado por la Asamblea General de dicha Organización, mediante la Resolución 2200 A (XXI) del 16 de diciembre de 1996. 
formen parte de su dignidad personal a partir de ser iguales y libres de poder tener esas calidades. No obstante ello, la concepción impersonal pone el énfasis en un criterio que, a diferencia del concepto personal, es importante destacar: las cualidades [personales] deben estar vinculadas a la función pública, es decir, con lo que signifique el cargo popular. ¿Y qué es lo que le pertenece al cargo? Pues los valores constitucionalizados de la función pública: honestidad, lealtad, libertad, eficacia y profesionalismo en el desempeño de la función pública, así como los principios rectores en materia electoral: equidad, legalidad, certeza, transparencia, etcétera. Pues lo que está en discusión es el conjunto de cualidades pertinentes de las personas para un cargo específico (Walzer 1997, 155). Es decir, el significado del cargo que se califica con las calidades del ciudadano que pretende el cargo. Eso es lo que se premia y puede ser objeto de calidades justas o injustas a exigir para poder ser votado en pie de igualdad.

Por otro lado, el problema de la concepción personal en su noción absolutista de la calidad para ser votado como inherente de la persona por formar parte de su ser, radica en que si bien no se pueden exigir calidades impersonales que no estén sujetas a la libre voluntad de los ciudadanos, también lo es que hay cualidades y circunstancias de las personas que son racionales exigir y que, además, no dependen necesariamente de la voluntad de ellas. La edad, por ejemplo, es una circunstancia que no depende de la voluntad de alguien (nadie se aumenta o disminuye la edad por propia voluntad, sino por una cuestión ajena a él como lo es su naturaleza temporal), pero sí es razonable exigir la edad conforme al principio de idoneidad. La residencia, por el contrario, es un requisito ordinario para ser votado que es parte de la libertad de cada quien: cada uno fija su residencia, pero en esencia residir en un lugar es un hecho no inherente a la persona porque nadie carga su domicilio en su persona para que sea inherente a él, ni tampoco uno nace con una residencia determinanda para siempre. Igualmente, es importante tener en cuenta que la cualidad inherente que se puede exigir para ser votado no implica una desvinculación con el cargo, dado que las cualidades a justificar tienen, necesariamente, que relacionarse con el cargo a aspirar como lo señala la concepción impersonal de las calidades.

Hasta aquí las cosas, es claro que las calidades como contenido esencial del derecho a ser votado implican, por un lado, todas aquellas que 
resulten propias de las personas, tanto porque formen parte de su situación o condición determinada como seres humanos, como aquellas que sean resultado de su libertad e igualdad. Es decir: no sólo se trata de poder imponer calidades al derecho de ser votado conforme a las características naturales de todos los seres humanos: la edad y su capacidad de obrar. También se trata de establecer cualidades y circunstancias que, aunque no son esencialmente intrínsecas a la persona, en estricto sentido, sí son resultado de la libertad personal: el residir en un lugar no es algo inherente de la persona como lo es su edad (nadie tiene adherido a su cuerpo la residencia), pero es una circunstancia que se puede determinar de manera individual a través de la libertad: cada quien es el que, conforme a sus posibilidades, escoge residir en tal o cual lugar. Ahora, lo que se excluye de las calidades es la calificación de que algunas circunstancias personales, naturales o no, pueden resultar notoriamente discriminatorias en determinados casos. Lo que se reprocha, entonces, es que las mismas no pueden exigirse a todos porque generan una situación de desventaja indebida que hace privilegiar a uno, excluyendo a otros de igual dignidad. Es decir, el título de doctor en derecho que resulta del mérito de cada quien y de su contexto social, cultural y económico, es una calidad de la persona porque resulta de su esfuerzo y logro, pero si dicha cualidad es exclusiva de una pequeña elite intelectual, es claro que no puede ser una calidad para poder participar políticamente, porque excluiría a la mayoría en la lucha por el poder. Igualmente: la edad puede ser un criterio igualitario para todos porque, en un momento determinado, llegada la edad exigida, podemos ser votados, pero es claro que dicha calidad no está sujeta a la voluntad de cada quien porque nadie puede escoger los años a cumplir. El género, por citar otro ejemplo, aunque sea una cualidad inherente de la persona, no puede servir de base para justificar el derecho de poder ser electo. No se puede privilegiar a un sexo en forma indebida: "los hombres sí son votados, las mujeres no". Pero si se puede justificar una regla de selectividad, no de elegibilidad, a la hora de preferir a un género subrepresentado en el poder, causado por el privilegio del otro que promueve de hecho la opresión de ese grupo minoritario, es claro que dichas situaciones que resultan de una cualidad natural, social y personal pueden servir para decidir quién será electo: las cuotas electorales de género justifican seleccionar a los grupos minoritarios. 
Las calidades para ser votado, por tanto, son consecuencia de la fórmula de que cada uno cuenta y vale por igual que otro: una cabeza, un voto igual, ${ }^{13}$ pero un voto igual significa también una oportunidad equitativa a ser votado. El derecho a ser votado (sufragio pasivo) tiene su núcleo esencial en la libertad a participar: todos los que votan pueden ser elegibles (igualdad política), pero no todos los elegibles pueden ser electos porque sólo uno lo será (idoneidad por ser seleccionado por un partido y elegido por la mayoría). Es decir, como el cargo público es escaso y único a distribuir (un bien unitario), es claro que los procesos que determinen la distribución del mismo "deben de ser equitativos para todo candidato" (Walzer 1997, 142). Pero ¿qué es ser equitativo en la lucha del poder? Ronald Dworkin formula el principio de "igualdad de poder", es decir, la igualdad de impacto y la igualdad de influencia para evaluar la equidad en el poder político. La primera significa que cada persona tiene derecho a participar: una cabeza, un voto; un voto, una posibilidad de ser votado; la segunda implica que esa cabeza que es la libertad del voto y el ser votado, no tiene más valor que el suyo, a fin de evitar la influencia injusta que describe a un solo individuo que concentra de manera desproporcional mayor poder político que otros: "es injusto que un ciudadano privado tenga mucha más influencia política que otro sólo porque es rico" (Dworkin 2003, 214). Es decir: el imperativo es que cada uno cuenta por uno, nadie cuenta por más de uno (Mill 1984, 58).

En tal sentido, no se pueden imponer cualidades, personales o no, que sean notoriamente desiguales (sólo unos pocos las tienen), o bien, que al ser habilidades o talentos naturales reproduzcan una notoria desventaja para luchar por el poder: por ejemplo, tiene derecho a ser votado, nada más el que sea más carismático, lo cual es inaceptable porque ello excluiría a todos los que no lo son. Pero sí se podría, no obstante, establecer reglas de selectividad que serán injustas o justas en la medida en que el ciudadano tenga un equitativo poder de influencia o impacto para lograr el poder: por ejemplo, la democracia dice que gana el que más votos tiene, por lo que si el voto se da por el carisma de las personas para atraer o fascinar al electorado, es claro que aunque no se elimine de la contienda

13 Un ciudadano/un voto significa el gobierno opuesto a la exclusión, a la degradación en la esfera de la riqueza material; equivale también al principio de la consideración equitativa en la esfera del cargo; es, por tanto, la garantía de una plaza escolar para cada niño en la esfera de la educación (Walzer 1997, 315). 
al menos carismático (calidad no justificada), no parece injusto que haya ganado el que más carisma tuvo para poseer el voto, si todos pudieron luchar por él en igualdad de condiciones. Luego entonces: todas las cualidades naturales y no naturales de las personas entran en juego en la noción de las calidades para ser votado. Nada más que no todas se justifican, porque lo que las califica es, justamente, las cualidades que le son propias a las personas, sea porque la naturaleza se las distribuyó como porque son resultado de su ejercicio de la libertad, pero en cualquier caso si dichas calidades sirven para sacar una ventaja indebida a los demás, deben excluirse si no hay una misma oportunidad de obtener la misma ventaja: por ejemplo, el rico como el pobre tienen derecho a luchar por el poder, pero la riqueza de uno no puede servir de base para imponer una cualidad que diga que sólo el hombre propietario y blanco tiene derecho a ser votado. Ergo: ninguna calidad personal, natural o no natural, que crea una desventaja indebida para beneficiar a unos pocos y excluir a la mayoría, puede justificar una cualidad para ser votado por más inherente que sea de la persona.

\section{D. ¿La conducta tránsfuga es una calidad constitucionalmente aceptable?}

Tomando como punto de partida la concepción mixta de las calidades para ser electo, la conducta transfuguista, consistente en decidir cambiarse de partido para ser postulado por el otro, es una circunstancia personal que depende de la voluntad de cada quien: es el tránsfuga el que decide conforme a su voluntad motivada por diversas razones (inmorales o no) ser presentado a las elecciones por un partido distinto al que pertenece o haya pertenecido. Me parece que allí está el yerro conceptual de la Corte en el caso Coahuila (2007): en no examinar el contenido central de la conducta a prohibir en el transfuguismo electoral. No se trata de saber si el no pertenecer a un partido diferente es una condición inherente a la persona, porque si de eso se hablará, la cuestión sería más bien un problema de falta de militancia partidista como requisito para ser votado como en el caso Hernández y otros (2004). El problema es más bien la militancia diferente por la movilidad política; esto es, que el ciudadano es postulado por un partido distinto al que pertenece o perteneció.

En tal sentido, a mi juicio las restricciones al derecho de ser votado por razones transfuguistas sí son parte de las calidades constitucionales 
que el legislador puede establecer para ser electo a un cargo representativo, dado que el cambiarse de un partido a otro para ir por una candidatura es una circunstancia personal que puede ser evaluada, positiva o negativamente, por el legislador en función de la libertad e igualdad de cada quien. ¿Esto significa que la norma tránsfuga es constitucional? No necesariamente. Pues una vez que se hace el análisis de las calidades en función de exigir cuestiones que formen parte de las cosas que un individuo puede hacer o no hacer razonablemente, resulta pertinente, entonces sí, entrar a un segundo nivel del test: la racionalidad o no de la calidad a examen, la cual se realiza a partir del principio de ponderación de los derechos humanos: idoneidad, necesidad y proporcionalidad de la regla antitransfuguista.

\section{La cuestión de la libre participación electoral}

Aquí hemos llegado a la segunda cuestión: la libertad política de participar en la selección de una candidatura. ¿Es razonable limitarla por deslealtad y traición a la hora de la selección de las candidaturas? La Corte en el caso Coahuila (2007) dijo:

los ciudadanos pueden afiliarse libre e individualmente a los partidos políti$\cos$, quienes contribuyen a la integración de la representación nacional, lo que implica, que se está ante un derecho fundamental, el de la libertad de asociación en materia política, el cual se confiere a los ciudadanos para constituir partidos políticos, que no tienen otro fin que el acceso a los cargos de elección popular y la configuración democrática del poder público, de ahí que si se considera como derecho fundamental el de la libre asociación política, es claro que la norma cuya invalidez se demanda restringe indebidamente ese derecho.

Me parece que aquí deben analizarse algunas cuestiones adicionales. En primer lugar, hay que dejar claro que el derecho a ser votado no es un "derecho absoluto" dado el principio de "sociedad democrática" que delimita los derechos políticos fundamentales, tal como ha argumentado el TEPJF desde los casos Alianza por Chiapas (2001) y Amador vs PVEM (2002). Esto es: no hay libertad política absoluta, se puede limitar en función de los fines y valores de las normas democráticas. En tal sentido, ¿por qué restringe indebidamente la libertad política la norma que regu- 
laba el transfuguismo en el caso Coahuila? La Corte es lacónica. Pero la opinión del TEPJF (SUP-AG-20/2007) es más explícita, aunque me parece que los argumentos del PT como actor en la acción de inconstitucionalidad fueron los más contundentes. Los argumentos de irracionalidad serían:

a. Porque si toda persona tiene derecho a asociarse y participar en un partido, también tiene el derecho de dejar de participar en él y ejercer su libertad para ser postulado por otro partido.

b. Porque el prohibir simple y llanamente la postulación de un candidato de un partido diferente, afectaría la libertad de los partidos para presentar candidatos externos, candidaturas comunes o coaliciones. ${ }^{14}$

Pero en realidad, ¿es irrazonable sancionar el transfuguismo electoral? Me queda claro que el que cuando una persona de manera libre deséa dejar de pertenecer a un partido para postularse por otro es una conducta que en principio debe estar amparada por la libertad política. El Estado debe respetar su libertad negativa y positiva de hacer política. La primera, porque para poder acceder a un cargo público representativo se requiere de que nadie interfiera con esta actividad. ${ }^{15}$ La segunda, dado que también se debe tutelar el interés de las personas, no sólo de no ser agredidos sino de ser autónomos: se quiere ser instrumento de sí mismo, no de la voluntad de otro: ser sujeto, no objeto; moverse por razones, por propósitos y acciones conscientes que le son propios y no ser inducido,

14 En el caso Coahuila (2007), el PT en su demanda ejemplificó los absurdos de la regla transfuguista al decir: a) una persona que libremente renuncia a su militancia en ejercicio de su libertad de expresión y asociación política, no puede hacer política en dos años después porque no podría ser postulado por otro partido a un cargo de elección popular; b) incluso, aquel que es militante de un partido y que pretende ser postulado por otro en vía de candidatura común o coalición, no podría ser electo porque otro partido lo estaría postulando, ya que caería en el supuesto de ser integrante de un partido, pero lo postula otro y, c) finalmente, una persona que fue integrante de un partido y que deja de pertenecer a él con anticipación por cualquier causa lícita, no podría luchar ni competir por el poder en los dos años siguientes, aunque dicho partido al que perteneció ya no tenga registro para participar o bien sea la principal causante de su renuncia o abandono por actos autoritarios que no hayan respetado sus derechos políticos.

15 La libertad política en sentido de la libertad positiva es el área dentro de la cual un hombre puede actuar sin que sea obstruido por otros; entre más amplia sea esa área, más libre es la persona (Dieterlen 1996, 57). 
en consecuencia, por causas ajenas que afectan su libre voluntad (Berlin 1978, 149 y ss). El ciudadano, por tanto, debe ser libre de escoger cuando se quiere ir o no de un partido para irse con otro en función de sus intereses y deseos legítimos. Pero esos intereses y deseos de las personas no siempre armonizan, con lo cual se acepta que la ley pueda imponer restricciones razonables, sobre todo cuando las consecuencias de algunas acciones repercutan en la libertad de otros (Dieterlen 1996, 57 y 58).

En tal sentido, no es razonable, por ejemplo, que la libertad política ampare la posibilidad de que una persona, al mismo tiempo, pueda tener una doble militancia por más libre que sea alguien, ${ }^{16}$ pues ello afecta el interes de otros: los partidos y militantes de los partidos que no saben a qué atenerse con el doble militante. En el caso González (2003), sin que lo haya dicho expresamente el TEPJF, la línea argumental central puede orientar la idea de que un militante no puede al mismo tiempo pertenecer a otro partido, pero el hecho de que sea postulado por otro partido no es razón suficiente para restringir sus derechos políticos en el partido en donde es militante (Ríos 2008, 157). Si esto es así, aún queda abierta la cuestión: si bien no sería válido tener doble militancia, es válido cambiar de partido en cualquier momento; es decir, tener dos o más militancias partidistas pero no al mismo tiempo.

La respuesta, a mi juicio, dependerá de cada caso concreto y según las causas, móviles y circunstancias del tránsfuga. Si alguien se cambia de partido para competir por otro por razones de compra de voto y de candidatura, negociación ilícita, cohecho, etcétera, me parece que tendremos buenas razones constitucionales, no sólo para penalizar esas conductas, sino para limitarlas en el ámbito electoral. Pero fuera de razones ilegales que constituyan un transfuguismo retribuido, me parece que tal conducta termina siendo una libertad de expresión que no debe tener censura previa ni limitación. Esto nos lleva, pues, al principio de lesividad como criterio para restringir libertades y derechos.

\section{La cuestión del principio de lesividad}

El PT en el caso de Coahuila (2007) argumento que la regla transfuguista no estaba justificada, dado que no se probaba la lesividad a terce-

16 El artículo 5.2 del Cofipe (2008) dice: "ningún ciudadano podrá estar afiliado a más de un partido político". 
ros o al sistema de partidos para poder justificar un límite razonable a ese derecho fundamental. Este es un argumento novedoso para examinar la cuestión: si la deslealtad o cambio de partido no causa un perjuicio no es dable entonces limitar la libertad transfuguista.

En efecto, se puede considerar inmoral o políticamente incorrecto, o al revés (moral o políticamente correcto) que alguien abandone un partido para ser postulado por otro, pero dicha circunstancia (de inmoralidad o moralidad política), es insuficiente para restringir el derecho a ser votado si es que no existen otras razones que justifiquen una lesividad al sistema de partidos y sus miembros. Esto nos lleva a aplicar el principio de lesividad que en materia constitucional se tiene que ponderar a la hora de justificar una restricción a una libertad. Si tomamos en cuenta la doctrina del "principio de lesividad" (Mill 1970; Hart 1981; Ferrajoli 1998) se puede llegar a sostener que el transfuguismo político entendido como el hecho de sancionar la libertad de una persona por ser integrante de un partido y ser postulado por otro, implica una intervención indebida del Estado en el plan de vida política que una persona escoge, sin que esa sola circunstancia implique un daño al sistema de partidos o a un tercero que sea necesario proteger. Cuestión diferente sería si, además del abandono partidista, se demuestra que se hace por un acto de corrupción o ilegal. Por tal razón, el transfuguismo electoral no tiene razones suficientes de lesividad al sistema político que justifiquen la restricción de un derecho fundamental. La norma no prueba que exista un ataque concreto a bienes fundamentales de tipo individual o social en los que se base la democracia, tampoco se ve que prohibiendo tal circunstancia de poder ser electo sea útil e idóneo para evitar daños al sistema de partidos, ni mucho menos se demuestra que la Constitución tenga como finalidad evitar que las personas tengan la libertad de asociarse o dejar de asociarse con un determinado partido, pues por el contrario, la finalidad de la libertad política implica el derecho de todo ciudadano de participar en la política con el partido que desee, pero también dejar de participar con ese partido cuando sus intereses y sus convicciones sean diferentes. Esa sería la argumentación.

La Corte tomó en cuenta aquí la opinión del TEPJF (SUP-AG-20/ 2007). En ella se señalaba que "los ciudadanos que hubiesen sido integrantes de un partido político distinto al que los postula cuando menos dos años antes de la fecha de registro de candidatos de la elección de que se 
trate, no se encuentran en las hipótesis de tener facultades de mando ni de disponer de la fuerza pública", por lo cual, el impedimento de ser autoridad no es equiparable. De igual forma el TEPJF opinó:

Dicho impedimento tampoco guarda semejanza con la causa de inelegibilidad para ocupar cargos de elección popular, prevista en la generalidad de las legislaciones, para quienes pertenecen al estado eclesiástico o son ministros de algún culto, cuya razón de ser estriba, fundamentalmente, en que, en su carácter de líderes religiosos, pueden influenciar en forma determinante a los electores que profesan las mismas creencias.

Y concluyó, por tanto, que el tránsfuga: "no tiene por consecuencia necesaria una influencia determinante en la generalidad de los electores". Estos argumentos fueron sintetizados por la Corte al decir en el caso Coahuila (2007) que "no tiene como consecuencia necesaria e inmediata una influencia determinante en la generalidad de los electores, por lo que esa circunstancia no compromete alguno de los principios electorales".

¿Esto quiere decir que el transfuguismo no causa perjuicio? No. Veamos las últimas cuatros cuestiones que pueden ser el hilo conductor para discutir la lesividad electoral del transfuguismo en una democracia representativa.

\section{La cuestión de la lealtad al partido y su base electoral}

¿Es válido establecer leyes que promuevan la lealtad y disciplina partidista? El asunto es saber si con base en ello se puede justificar el transfuguismo para tutelar la lealtad al partido. En México, la democracia partidista ha cobrado relevancia a partir de la última década. De un Estado de partidos autoritario basado en el "sistema hegemónico-pragmático" (Sartori 2000, 279), hemos empezado a ensayar, desde la reforma de 1996 a la fecha, el control judicial de la vida interna de los partidos bajo el principio democrático (Castillo González 2004). Este modelo de control escenifica, por un lado, la lucha que dan los militantes de los partidos a la hora de hacer política, pero por otra parte, sintetiza una alternativa jurídica para sanear la vida política frente a la crisis de legitimidad de 
los partidos, ${ }^{17}$ el cual se explica, entre otras cuestiones, por el déficit democrático de la clase política (Cárdenas Gracia 1992; Cascajo Castro 1992; Aragón Reyes 1999).

Bajo esta idea los partidos fijan sus reglas estatutarias para normar su convivencia interna a partir de una esfera de autonomía que garantiza la Constitución y regula el COFIPE. Una regla básica es la disciplina partidista: todos los militantes deben cumplir ciertos deberes partidistas que en el fondo se traducen en reglas de conductas y de comportamientos partidistas, so riesgo de ser sancionados en caso de incumplimiento. Es la otra cara de la democracia interna de los partidos: aquella en la que se construyen deberes - no sólo derechos - a la hora en que los militantes participan en la vida partidista (Ríos 2008). Es decir, la democracia como principio rector en la vida interna partidista, no sólo exige un contenido mínimo de derechos políticos que expresan la "esfera de lo indecidible de la mayoría", sino también un contenido mínimo de deberes políticos que expresa la "esfera de lo decidible por la mayoría" (Ferrajoli 2001a). Por citar un caso: si un partido, dentro de su autonomía partidista, impone por igual reglas democráticas para seleccionar a sus candidatos en forma directa y abierta (con el voto de sus militantes o ciudadanos), pero también exige deberes de lealtad y de conducirse de manera disciplinada en dichos procedimientos internos, es claro que cada militante tendrá derecho a participar en la selección, siempre y cuando observe los deberes partidistas para poder ejercer sus derechos políticos. Ese es el punto.

Pues bien, la democracia de partidos implica que la mayoría no pueda negociar o alienar los derechos políticos fundamentales en la organización y funcionamiento interno de un partido político, porque es parte del "coto vedado" (Garzón Valdés 1989) que se diseña en un Estado constitucional de partidos. Pero cada ciudadano tiene que ejercer sus derechos

17 En el caso mexicano, la crisis de la representación política es palpable. El último lugar del índice de confianza institucional lo ocupan los diputados con el 6.1 de una escala de 10, inmediatamente después siguen los sindicatos y los partidos con el 6.2, mientras que la policía y los senadores con el 6.3 (Consulta Mitofsky, Índice de confianza en instituciones, agosto de 2006, México). Con lo cual es claro que la vía judicial para hacer efectiva la democracia interna en los partidos es, por sí misma insuficiente, no por ello innecesaria, por su objeto esencialmente correctivo (sancionar y reparar violaciones), pero no preventivo de los males de la llamada "globalización de la kakistocracia" que impera por el dominio de personas aptas para las democracias degeneradas (Bovero 2006, 48). 
en el marco de un conjunto de deberes democráticos, justificados y racionales, de tal manera que la mayoría partidista puede imponer válidamente ciertas condiciones, requisitos y límites a la hora de participar en la selección de las candidaturas. Esto es: el militante no sólo tiene una carta de derechos que pude exigir en la vida de un partido, sino que éste, también, puede reclamar a aquél una carta de deberes razonables y proporcionales a su derecho a la participación política. La doctrina señala que la categoría imperativa de una vida interna democrática para los partidos despliega su alcance no sólo en los derechos políticos, sino también en los deberes de los afiliados. Lo anterior es así, porque atentaría contra el principio democrático aquel estatuto partidista que sometiera a sus miembros a obligaciones gravosas, irracionales o desproporcionadas con la función propia de los partidos en la democracia constitucional (Navarro Méndez 1999, 499).

¿cuándo un deber de lealtad partidista es inusitado, desproporcionado o irracional?, me parece que es una de las cuestiones pendientes de discutir en el transfuguismo. De entrada planteo sólo mi tesis: el únicamente hecho de cambiarse de partido y postularse por otro no debe significar para nadie una restricción a su libertad electoral, a menos que la movilidad partidista cause un perjuicio concreto e injustificado: el desplazamiento arbitrario de otros militantes en la selección de la candidatura, la compra de la candidatura para generar deliberadamente divisionismo, la desleltad grave a las reglas del juego interno que sean democráticas, etcétera.

\section{La cuestión de la titularidad de la candidatura}

Una de las razones que se expresan para justificar el transfuguismo electoral reside en la titularidad del cargo que pertenece al elegido y no al partido: éste no puede restringir a aquél porque el dueño del cargo público representativo es el ciudadano (Tomás Mallén 2002, 94 y ss.). La cuestión que habría que replantear aquí es la siguiente: ¿a quién le pertenece la titularidad de la candidatura: al partido o a los ciudadanos?

Es claro que la democracia actual se basa, articula y funciona en el marco del "Estado de partidos" (García-Pelayo 1986; Blanco Valdés 1990; Hernández Oliver 2003). La teoría de los partidos, por su parte, justifica la necesidad de ellos: el "único tipo de organización que puede traducir en hechos la idea del gobierno de la mayoría es el partido políti- 
co" (Schattschneider 1948, 10). Son los partidos los que organizan la "caótica voluntad pública" (Neumann 1956, 397), convirtiéndose así en "la canalización política de la sociedad" (Sartori 2000, 63). Es simple. "Los partidos son inevitables. Ningún país grande y libre ha carecido de ellos. Nadie ha demostrado cómo podría funcionar un gobierno representativo sin ellos" (Bryce 1921, 119). Los partidos, ergo, son necesarios para la democracia. La voluntad colectiva se forma con la libre concurrencia de grupos de interés constituidos en partidos políticos.

Dicho de otra manera: hacer política implica competir en la distribución, la conservación o la transferencia del poder (Weber 2004, 84). La razón de ser de los partidos y su papel es la representación de la sociedad en el gobierno representativo (Sartori 2000, 55), por lo cual es en la esfera de los partidos en donde se hace política para luchar por el poder, para acceder a él, ejercerlo y mantenerlo. El elector decide entre los que los partidos seleccionaron. Escoge entre los candidatos cooptados por la clase partidista, lo cual constituye el primer acto de la operación electoral, del que la elección no es más que el segundo. Se genera, en suma, la apariencia de decidir, porque la ciudadanía vota personalmente por $\mathrm{X}$ o $\mathrm{Y}$, pero $\mathrm{X}$ o $\mathrm{Y}$ han sido seleccionados por el partido, quien decide la lista y su clasificación (Duverger 1988, 397). Ello es así, porque los partidos funcionan como instrumentos básicos para traducir las preferencias de las masas en opciones para la distribución del poder (Key 1961, 433). Esto es: el partido como cualquier grupo de poder aspira a obtener votos bajo una etiqueta reconocible (Epstein 1967, 9), a fin de cumplir una de sus principales funciones constitucionales: presentar candidatos a las elecciones (Laswell y Kaplan 1950, 169-171) para ganar el poder. Es decir: los partidos son organizaciones que persiguen, ante todo, el objetivo de colocar a sus representantes en las apuestas del gobierno, los cargos públicos (Janda 1970, 83). Sí, por eso compiten los partidos, por el poder; se forman en el estado constitucional de derecho para ser las vías de acceso a los cargos populares; los partidos al final de cuentas hacen posible la democracia representativa, la poliarquía competitiva (Dahl 2002). Luego entonces, si los partidos son necesarios para la democracia, el problema central radica en definir en clave constitucional el modelo de su democracia interna. Pues los partidos, en países democráticos, son, por lo general, mucho más oligárquicos que democráticos (Dahl 1994, 14). La cuestión a discutir implica, por tanto, el análisis de las diferentes concep- 
ciones del imperativo legal de que los partidos funcionen y se organicen democráticamente, a partir de una doble dimensión: real como jurídica (Navarro Méndez 1999). En consecuencia, el discurso de la filosofía política y de derecho, así como la ciencia jurídica constitucional y electoral, serán métodos útiles a la hora de justificar las reglas que le dan contenido, alcance y límites a la democratización de los partidos y su control.

Sin embargo, los partidos no deben ser dueños de la candidatura por una sencilla razón: el ser candidato forma parte del derecho a ser votado. La oportunidad de ser candidato, por tratarse de un derecho político fundamental, no puede resultar negociable, disponible, violable y alienable por parte de los partidos. En un Estado democrático de derecho las reglas deben construirse sobre la base de los derechos político-electorales. La legitimidad de la representación política a partir del derecho a participar en la formación de la voluntad soberana es parte de su esencia (Kelsen 1977). Es por ello que la posibilidad de ser elegido popularmente tiene que ver con las reglas del juego y que, por tanto, la función del derecho radica en racionalizar el acceso al poder para garantizar la oportunidad del ciudadano de competir, ganar y permanecer en el poder con principios democráticos. Ello es así, pues en la medida en que se proteja el derecho de ser votado se asegura, al mismo tiempo, la racionalización de la lucha por el poder para maximizar la democracia. En efecto, la participación política de los ciudadanos en la formación de la voluntad estatal (derechos políticos), entraña la pretensión de que sea aceptada la papeleta entregada por el elector, y de que el Estado, otros hombres encargados de otra función orgánica, hagan el recuento de los votos emitidos y proclamen el resultado de la elección (Kelsen 2002, 257). Pero antes de que cuenten los votos, cuenta también la selección de los partidos en la candidatura. Es allí en donde el derecho a ser electo tiene una vinculación con los partidos: antes de que el pueblo elija, la minoría partidista selecciona al que será electo.

Pues bien, me parece que en la titularidad de una candidatura confluyen dos derechos a reconocer en la democracia: el de la persona que pretende participar, sin restricciones indebidas y en igualdad de oportunidades, para poder ser postulado por un partido como candidato, así como el del partido que, a partir de reglas democráticas, tiene que seleccionar a aquel que competirá en su nombre por el voto popular. Este doble interés justifica reglas de derecho que tutelen a ambos y, por ende, la candidatu- 
ra puede estar sujeta a reglas de selectividad que premien la lealtad partidista y castiguen la traición retribuida por un transfuguismo socialmente inaceptable. En el caso Albores (2006), por ejemplo, el TEPJF confirmó la sanción de un militante de un partido que ocupó el cargo de gobernador en el estado de Chiapas, y que situado como un cuadro destacado del PRD, pidió el voto por un candidato opositor, el del PRI, con lo cual lesionó la unidad de partido y confundió a la militancia de su partido, motivo por el cual se le expulsó. Este tipo de deslealtad es la que sin ir por una candidatura por otro partido, apoya públicamente al candidato opositor de su partido. Lo cual justifica la sancionabilidad de la conducta de apoyar a un partido diferente al que se pertenece. Pero, ¿sería válido que este tipo de tránsfuga fuera premiado con una candidatura del partido que indebidamente apoyo? Me parece que esos son los problemas que habría que discutir: no es muy sano que, además de dividir a su partido por su interés personal que perjudica a su base electoral, se vea premiado por una candidatura de otro partido que le de una nueva representatividad política. Es discutible.

Por tanto, el problema será analizar en cada caso concreto y según los móviles y circunstancias probadas, porque no todo transfuguismo debe ser reprochado en la vida interna de un partido. Esto nos lleva a un problema más: la autonomía partidista.

\section{La cuestión de la autonomía partidista}

El PT en el caso Coahuila (2007) argumentaba que la regla antitránsfuga implicaba una intromisión injustificada a la vida interna de los partidos políticos, pues se les imponían restricciones en la postulación de sus candidatos, máxime que es una prerrogativa de los partidos políticos la de postular candidatos a elección popular con base en su normatividad interna, la que contempla en la generalidad de los institutos políticos, la posibilidad de postular candidatos ciudadanos o externos, sin que sean militantes de los partidos políticos de que se trata.

Los partidos, en efecto, operan conforme a "la ley de hierro de la oligarquía”, en tanto que, por lo regular, el poder entre la clase política se desplaza, y concentra, a, y, en, los órganos directivos de los partidos, la cúpula, la cual amplía su poder en la medida en que crece la necesidad de organizarse de manera oligárquica (Michels 1979, 256). Se trata, 
pues, de la cuestión de la partidocracia: la clase política ${ }^{18}$ tiende a constituirse en una casta más o menos cerrada, un círculo interior que cohesiona tanto a los líderes aparentes como reales, en donde la paradoja es clara: mientras que la elección por sufragio universal, por definición, debería impedir el nacimiento de la oligarquía; de hecho, más bien tiende a favorecerla (Duverger 1988, 181). Ello es así, pues los partidos detentan el monopolio de las candidaturas y, por tanto, un "político sin partido es un político sin poder" (Dahl 1994, 90), por lo que es una norma (casi inmutable) que el representante popular, antes de ser escogido por sus electores, es seleccionado por el partido: la ciudadanía, por su parte, no hace más que ratificar la decisión previa de la minoría partidista (Duverger 1988, 378).

El tema es actual. Más ahora con la reforma electoral de 2007, ${ }^{19}$ la que, por un lado, constitucionaliza la intervención de las autoridades electorales en la vida partidista con base en la Constitución y ley, ${ }^{20}$ pero también ofrece, por otra parte, la oportunidad del legislador secundario de imponer un círculo (de no intervención) a los actos partidistas, el cual sólo puede ser erradicado por el discurso del más débil, el de los derechos (Ferrajoli 2001b). La discusión se debe centrar en determinar la es-

18 La "ley de la clase política" significa que toda sociedad se configura como una pirámide, una estratarquía, en donde hay dominantes y dominados: los primeros son una minoría, la clase política (Mosca 1984, p. 130).

19 El último párrafo de la fracción I del artículo 41 de la Constitución, en lo conducente dice: "Las autoridades electorales solamente podrán intervenir en los asuntos internos de los partidos políticos en los términos que señalen esta Constitución y la ley".

20 El texto aprobado por la reforma electoral de 2007 pudiera tildarse de absurdo: todo acto de autoridad debe sujetarse a la Constitución y la ley. Pero si se lee en clave legalista, la norma aprobada permite el diseño de un espacio de autonomía partidista en el que se diga qué cosas pueden ser objeto de intervención por parte de las autoridades electorales, y qué cosas no. Algo que igualmente se puede tildar de perogrullada (porque aunque no lo dijera, es obvio que el legislador lo podía hacer), pero que según la interpretación jurídica — allí está el detalle- puede tener resultados diferentes y excluyentes. A mi juicio, la norma constitucional de la intervención partidista significa dos cosas. La primera: la vida interna de los partidos debe sujetarse a los principios de la democracia constitucional; la segunda, que los partidos tienen derecho a autodeterminarse conforme al principio de legalidad y que, por tanto, sólo se puede tener un control externo por parte de la autoridades electorales en la medida en que lo permita la interpretación de la Constitución y la ley. El asunto no es banal, porque implicará la concepción que los jueces determinen para defender derechos políticos: la interpretación restringida o amplia, según los temas en discusión. 
fera de lo indecidible y cuál sería la esfera de lo decidible en torno al derecho de los partidos a autodeterminarse.

Sin duda, la democracia interna de los partidos plantea una serie de problemas que, desde antes, se pronosticaban, como la orientación que en el futuro iban a tener las cuestiones electorales (Woldenberg 2003, 357-363). Los números, incluso, no mienten: más del 70\% de los casos que se plantean en el TEPJF, se refieren a los derechos políticos, ${ }^{21}$ entre los que destacan, por supuesto, las cuestiones que forman parte de la "definición mínima de la democracia interna” (Navarro Méndez 1999, 75 y ss.). La importancia del tema es crucial. Ni la ley, menos los partidos políticos, pueden imponer reglas internas que afecten los derechos políticos; así, por más que una mayoría (legislativa o partidista) lo apruebe, no es válido establecer restricciones injustificadas para poder asociarse, afiliarse y competir: los requisitos conforme a la Constitución, son los únicos que se deben exigir para poder participar en la vida política. El legislador y el partido tienen vedado ir más allá porque, en lugar de facilitar el acceso al poder, lo obstaculizarían en perjuicio de la ciudadanía.

La línea argumentativa a seguir radica en el equilibrio entre el principio de autorregulación partidaria frente a los principios democráticos que todo partido debe garantizar en su vida interna, a fin de asegurar la eficacia de los derechos político-electorales. En el caso Amador vs. PVEM (2002) se definió el contenido mínimo de la democracia en los partidos y con base en ella, por tanto, se han aportado las soluciones a las cuestiones concretas que se han presentado: cuestiones de elegibilidad, acceso a la candidatura, sanciones partidistas, entre otras.

En suma. La disponibilidad de las reglas por parte de la mayoría o minoría partidista tiene su límite en los derechos políticos. Es así de claro: el derecho a competir delimita lo que la mayoría (más aún la minoría partidista) pueden hacer, pero también lo que no pueden hacer en el sistema de partidos. La pregunta es: ¿puede un partido, en ejercicio de su

21 Del 1o. de noviembre de 1996 al 26 de octubre de 2007, los JDC ocupan el primer lugar de la demanda de justicia electoral con un $71.16 \%$ del total de juicios recibidos en el TEPJF. Los JRC y los RAP también plantean casos vinculados con el tema, tales como cuestiones de elegibilidad de candidatos, reglas de competencia partidista, constitucionalidad de estatutos, sanciones partidistas, etcétera. Los RAP representan el 3.27\% y los JRC el $17.40 \%$ de los asuntos. TEPJF, Coordinación de Jurisprudencia y Estadística Judicial, Dirección de Estadística Judicial, http://www.trife.gob.mx. 
autonomía para fortalecer su unidad y cohesión política, regular reglas antitransfuguistas en su vida interna? El debate queda abierto.

\section{La cuestión de las precampañas}

Finalmente, llegamos a una variable del problema. La Corte ya dijo que no se pude limitar el derecho de alguien de ser postulado por otro partido; pero será lo mismo cuando ese alguien ya participó en el proceso de precampaña de su partido? Se trata del caso Distrito Federal (2008). En efecto, en el mes de febrero de 2008 el PT presentó una acción de inconstitucionalidad en contra de la fracción IV del artículo 222 del Código Electoral del Distrito Federal, que en lo conducente dice: "Son requisitos para ocupar un cargo de elección popular, además de los señalados por el Estatuto de Gobierno del Distrito Federal, los siguientes: IV. Los partidos políticos procurarán no registrar candidatos, que habiendo participado en una precampaña por un partido, pretendan ser registrados por otro en el mismo proceso electoral".

Pues bien, la cuestión plantea un problema que tienen antecedentes. En el caso Luna (2007), por ejemplo, el TEPJF analizó un precepto de la legislación electoral de Morelos similar, el cual establece que durante el mismo proceso electoral, no podrán registrarse como candidatos a un cargo de elección popular quienes en los procedimientos de selección interna de otro partido político hubieren perdido su nominación. Es decir, si una persona participa en un procedimiento interno de selección de candidatos de un determinado partido político, y no obtiene la postulación, no puede ser registrado por otro instituto político. Es decir: el que perdió con uno no puede jugar con otro. El TEPJF justificó la finalidad de esta norma al decir que dicha prohibición encuentra su razón de ser en la salvaguarda de los derechos de los afiliados de un determinado partido político, así como la congruencia y consistencia política de los participantes en un procedimiento interno de selección de candidatos, con lo cual, también se fortalece el sistema de partidos políticos al desestimular el transfuguismo por el mero motivo de no haber obtenido alguna postulación. En otras palabras: no es válido participar en unas reglas partidistas, no aceptar el resultado desfavorable y luego buscar la postulación por otro partido, lo cual puede desplazar sin causa justa a alguien que tenga mejores méritos dentro de ese instituto político para ganar la candidatura. Se sanciona, pues, el no saber perder: si participas en un partido y no 
ganas, ello no te da el derecho a cambiar de siglas porque perjudicas a los militantes de ambos partidos.

En la opinión del TEPJF (SUP-AG-10/2008) se desarrolla esta línea argumentativa en contra del transfuguismo en precampañas, a partir de las razones siguientes:

1. En toda precampaña el aspirante a la candidatura difunde su posicionamiento personal, de acuerdo con su filiación e ideología partidista, de tal manera que si después estuviera en aptitud de ser postulado por otro partido, ello podría generar confusión entre los electores quienes no identificarían cabalmente cuáles son sus principios y programas ideológicos, lo cual vulnera el principio de certeza y el voto informado, libre y razonado.

2. El hecho de que un partido político postulara a un candidato que ya participó en la precampaña por otro partido, también podría repercutir en los derechos de los demás militantes, vulnerando el principio de igualdad, al limitar las legítimas aspiraciones de otros ciudadanos que sí se sujetaron a los procedimientos internos para la selección de candidatos, situación que generaría el debilitamiento del sistema de partidos políticos al presentarse como opciones políticas poco serias.

3. Si un ciudadano por voluntad propia y libre decisión participa en una precampaña en un partido, es claro que se está sujetando a las reglas que regulan esa actividad con la finalidad de ser postulado por él, lo cual excluye la posibilidad de participar en la precampaña de otro.

Me parece que estos argumentos abren una nueva discusión. Son razones, a mi juicio, para repensar en cada caso concreto, porque así como habrá claros ejemplos de bandolerismo político que afecten el sistema de partidos, también existirán supuestos en donde un militante que participe en un proceso de precampaña de su partido, por los vicios y arbitrariedades de las reglas impuestas por la mayoría, no tenga otra opción que la movilidad política para ejercer su derecho a acceder a un cargo público representativo. Lo cual replantearía las cuestiones concretas en la sede del TEPJF si la norma del Distito Federal se valida por la Corte. ${ }^{22}$

22 Hasta la conclusión de este trabajo, está pendiente de resolver la acción de inconstitucionalidad 58/2008 y sus acumuladas, relativa al caso Distrito Federal. 


\section{UN APUNTE FINAL}

El juego de las traiciones y simulaciones es consustancial a la hora de hacer política. El transfuguismo plantea un debate desde la filosofía: si es aceptable o no permitir las traiciones en el marco de la libertad política. Por un lado, al tránsfuga se le asocia con los aspectos más negativos de la naturaleza humana: traición, deslealtad, codicia, oportunismo, avaricia, doblez. Por el otro, la conducta tránsfuga puede ser una virtud cívica del buen republicano: romper y oponerse al grupo del poder para promover el cambio político. Esto es: hay tránsfuga que "no son tan malos" y que forman parte del cambio democrático de un país (Rubio Llorente 1993, 13; García Roca 1995, 77 y ss.).

Desde el plano de la teoría política el debate del transfuguismo plantea reflexiones en torno al mandato representativo (Tomás Mallén 2002, 81 y ss.), en tanto que los electores pretenden que el sujeto que elijieron y que, por tanto, debe velar por sus intereses para hacer funcionar el sistema de gobierno, necesita de la "disciplina partidista" (Sartori 1996, 205 y ss.) que cohesione y le dé viabilidad al plan de gobierno por el cual van a votar, lo cual exige buscar el equilibro entre la autonomía individual y colectiva y que, sin duda, encontrará una mejor respuesta en el discurso de los derechos fundamentales. ${ }^{23}$ Pero, además, la relevancia de los partidos y la necesidad de construir una clase política leal al mandato ideológico que representan, hace necesario tomar una posición en torno al

23 En el caso Arámbula (2007), el TEPJF decidió que ningún legislador puede ser sancionado por su partido o grupo parlamentario por ejercer su libertad de pensar o ideológica, por lo que permanecer en una sesión para votar el paquete económico de un gobierno opositor, cuando su partido había decidió no hacerlo, no es causa para fundar una sanción al legislador que lo aprobó. El discurso judicial sostiene que "la disciplina y cohesión constituyen elemento angular de su vida interna de un partido político y de su papel en los parlamentos", pero ello no "pueden llegar al extremo de suprimir el goce y ejercicio de los derechos y libertades fundamentales de los afiliados o militantes". La autonomía de los congresistas para expresar sus ideas en el congreso, afirma el TEPJF, es un rasgo esencial de las democracias representativas por su función deliberativa. Por tanto, si bien el propósito de formar grupos hacia el interior de un órgano popular, es defender los postulados y enunciados básicos de los partidos que los postularon (programas de gobierno o legislativos), así como tomar decisiones conjuntas para cuestiones instrumentales, operativas y organizacionales, se debe reconocer al mismo tiempo el "constante equilibrio y respeto hacia la ciudadanía que los eligió como legisladores", a través de la libertad de sus representantes. 
transfuguismo electoral retribuido, es decir, aquel que resulta inaceptable socialmente porque divide deliberadamente la vida interna partidista, promueve el bandolerismo, fragmenta la base electoral, desplaza a los militantes leales y provoca indefiniciones políticas que afectan la relación de confianza y credibilidad entre electores-partidos.

Hay que discutir pues la permisión o prohibición del transfuguismo electoral en el sistema presidencial mexicano. En principio, el abandono partidista no puede justificar la pérdida a ser electo ni mucho menos a un cargo electo. En todos los países democráticos existe la libertad parlamentaria que permite a los políticos ser fieles a sus convicciones y los salva de permanecer con grupos o partidos que han cambiado su orientación de modo inaceptable para ellos. Luego, el hecho de que un ciudadano pertenezca a un partido en un determinado contexto de su carrera política, no puede justificar la renuncia ni la sanción mucho menos el impedimento para ser electo, si abandona dicho partido y es postulado por otro, pues se estaría afectando el núcleo del derecho a ser electo que implica la oportunidad de participar en la vida política sin restricciones irracionales, absurdas, ilógicas o discriminatorias.

Pero también aquí he expuesto que existen razones válidas para que en cada caso concreto se puedan construir reglas en la vida interna para calificar cuándo el transfuguismo electoral debe ser limitado sin vicio de constitucionalidad. He hecho aquí un apunte de estas cuestiones que merecería, incluso, un examen por separado, pero creo que el presente trabajo sirve de base para esta nueva discusión que tendrá que dilucidar cuándo y en qué circunstancias un deber de lealtad partidista es razonable exigir para evitar el nomadismo político retribuido que afecte los valores democráticos.

\section{BIBLIOGRAFÍA}

ARAGÓN Reyes, M., Constitución y control del poder: introducción a una teoría constitucional del control, Colombia, Universidad Externado de Colombia, 1999.

Aguiar DE LuQue, L., "Derecho de participación”, en AlzagA VillaAMIL, O. (coord.), Comentario a las leyes políticas, Madrid, Edersa, 1984, t. II. 
Berlin, I., "Two Concepts of Liberty” en Quinton, A. (ed.), Political philosophy, Oxford, University of Oxford, 1978.

BobBiO, N., Teoría general de la política, trad. de A. de Cabo y G. Pisarello, Madrid, Trotta, 2003.

BLANCO VALDÉS, R., "Cargos públicos, partidos, sociedad: la revolución de las primarias", Anuario de Derecho Parlamentario, Cortes Valencianas, 1998, núm. 6.

- Los partidos políticos, Madrid, Tecnos, 1990.

Bovero, M., "Democracia y derechos fundamentales", Isonomía, México, ITAM, 2006.

BRYCE, J., Modern Democracies, Nueva York, The Macmillan Company, 1921, vol. I.

Brandenburg, F., The Making of Modern Mexico, N. J., Englewood Cliffs, Prentice Hall, 1967.

CAAMAÑO, F., El derecho de sufragio pasivo, Navarra, Aranzadi, 2000.

CANSINO, C., "La transición mexicana 1977-2000", México, Centro de Estudios de Política Comparada, 2000.

CÁRDENAS, J., Crisis de legitimidad y democracia interna de los partidos políticos, México, Fondo de Cultura Económica, 1992.

CASCAJO CASTRO, J. L., "Controles sobre los partidos políticos", en GONZÁleZ EnCINAR, José Juan (coord.), Derecho de partidos, Madrid, Espasa Calpe, 1992.

CASTILlO GONZÁLEZ, L., "Los derechos de la militancia partidista y la jurisdicción", México, TEPJF, 2004.

DAHL, R., La democracia y sus críticos, trad. de L. Wolfson, Barcelona, Paidós, 1992.

—_ ¿Después de la revolución? La autoridad en las sociedades avanzadas, trad. de M. Florencia, Barcelona, Gedisa, 1994.

DieTERlen, P., Ensayos sobre justicia distributiva, México, Fontamara, 1996.

DUVERGER, M., Los partidos políticos, trad. de J. Campos y E. González, México, Fondo de Cultura Económica, 1988.

DWORKIN, R., Virtud soberana. La teoría y la práctica de la igualdad, trad. de M. J. Bertomeu y F. Aguilar, Barcelona, Paidós, 2003.

EPSTEIN, L., Political Parties in Western Democracies, Nueva York, Praeger, 1967.

FERRAJOLI, L., Derecho y razón. Teoría del garantismo penal, trad. de Perfecto Andrés et al., Madrid, Trotta, 1998. 
—_, Derechos y garantías. La ley del más débil, Madrid, Trotta, 2001a. — El garantismo y la filosofía del derecho, Bogotá, Universidad Externado de Colombia, 2001b.

GARCíA Murillo, J., La democracia en España, Madrid, Alianza, 1996. García-Pelayo, M., El estado de partidos, Madrid, Alianza, 1986.

GARCÍA ROCA, J., "La díficil noción de cargo público representativo y su función delimitadora de los derechos fundamentales del artículo 23.2 de la Constitución", Revista de las Cortes Generales, 1995, núm. 34.

- Cargos públicos representativos. Un estudio del artículo 23.2 de la Constitución, Pamplona, Aranzadi, 1999.

—_ "Los derechos de los representantes: una regla individualista de la democracia", Parlamento y Constitución, Cortes de Castilla-La Mancha, Universidad de Castilla-La Mancha, 2000, núm. 4.

GARZÓN VALDÉS, E., "Algo más acerca del «coto vedado»”, Doxa, núm. 6, 1989.

HART, H. L. A., Law, Liberty and Morality, Londres, Oxford University Press, 1981.

HERNÁNDEZ OlIVER, B., "Parlamento y estado de partidos. La democracia contemporánea", Revista de las Cortes Generales, núm. 60, 2003.

JANDA, K., A Conceptual Framework for the Comparative Analysis of Political Parties, Beverly Hills, Sage Publications Comparative Political Series, 1970.

KELSEN, H., Esencia y valor de la democracia, trad. de R. Luengo y L. Legaz, Barcelona, Labor, 1977.

— Comares, 2002.

KeY, V. O., Public and American Democracy, Nueva York, Knopf, 1961.

MANIN, B., Los principios del gobierno representativo, Madrid, Alianza, 1998.

MARTÍN NUÑEZ, E., El régimen constitucional del cargo público representativo, Barcelona, Cedecs, 1996.

Michels, R., Los partidos políticos 1. Un estudio sociológico de las tendencias oligárquicas de la democracia moderna, Buenos Aires, Amorrortu, 1979.

MiLL, J. S., De la libertad, del gobierno representativo, la esclavitud femenina, trad. de M. C. de Iturbe, Madrid, Tecnos, 1965.

—_El utilitarismo: un sistema de la lógica, trad. de E. Guisán, Madrid, Alianza, 1984. 
— Del gobierno representativo, trad. de M. C. de Iturbe, Madrid, Tecnos, 1986.

— Sobre la libertad, trad. de P. de Azcárate, Madrid, Alianza, 1970.

MuÑOZ, V. et al., Partido Revolucionario Institucional 1946-2000. Ascenso y caída del partido hegemónico, México, Siglo XXI, UNAM, 2006.

NAVArRo MéndeZ, J. I., Partidos políticos y “democracia interna”, Madrid, Centro de Estudios Políticos y Constitucionales, 1999.

— -Patalogía del transfuguismo político: grandes males, pero ¿buenos remedios?, Revistas de las Cortes Generales, núm. 49, 2000.

NoHLEn, D., Sistemas electorales y partidos políticos, México, Fondo de Cultura Económica, 2004.

Neumann, S., Modern Political Parties, Chicago, The University of Chicago Press, 1956.

PITKIN, H., El concepto de representación política, Madrid, Centro de Estudios Constitucionales, 1985.

PULIDO QUECEDO, M., El acceso a los cargos y funciones públicas. Un estudio del artículo 23.2 de la Constitución, Madrid, Parlamento de Navarra-Civitas, 1992.

Rallo Lombarte, A., Garantías electorales y Constitución, Madrid, Centro de Estudios Políticos y Constitucionales y Boletín Oficial del Estado, 1997.

RENUI I VILAMALA, J. M., "La representación política en crisis: el transfuguismo como estrategia política”, en PORRAS NADALES, A. J. (coord.), El debate sobre la crisis de la representación política, España, Tecnos, 1996.

Ríos, L. E., La sanción partidista en el PAN: el caso González, México, 2008, Serie comentarios a las Sentencias del Tribunal Electoral, TEPJF, núm. 5.

RODRíGUEZ, Á., "El Estado de partidos y algunas cuestiones de derecho electoral" Revista de Derecho Político, núm. 31, 1990.

RODRÍGUEZ RAMOS, L., "Transfuguismo retribuido y cohecho", Actualidad Penal, núm. 22, 1994.

RuBio LlORENTE, F., "Los tránsfugas no son tan malos", El País, 6 de octubre de 1993.

SÁNCHEZ, A. et al., Las elecciones de Salinas. Un balance crítico a 1991, México, FLACSO, Plaza y Valdés Editores, 1991.

SALAZAR, O., El candidato en el actual sistema de democracia representativa, Granada, Comares, 1999. 
SARTORI, G., "En defensa de la representación política", Claves de Razón Práctica, núm. 91, 1999.

—, Partidos y sistemas de partidos, trad. de F. Santos Fontela, Madrid, Alianza, 2000.

SCHATTSCHNEIDER, E. E., The Struggle for Party Government, Maryland, University of Maryland, 1948.

SORIANO, R., "El transfuguismo: estafa política a la voluntad ciudadana", Derecho y Libertades, Madrid, UC3M, 2002, núm. 11.

TOMAS MALLÉN, B., Transfuguismo parlamentario y democracia de partidos, Madrid, Centro de Estudios Políticos y Constitucionales, 2002.

VÁZQUEZ, R. (comp.), Corte, jueces y politica, México, Fontamara-Nexos, 2007.

WALZER, M., Las esferas de la justicia. Una defensa del pluralismo y la igualdad, trad. de H. Rubio, México, Fondo de Cultura Económica, 1997.

WEBER, M., El político y el científico, trad. de F. Rubio Llorente, Madrid, Alianza, 2004.

WOLDENBERG, J., "Orígenes, función y perspectivas del Tribunal Electoral del Poder Judicial de la Federación", Testimonios sobre el desempeño del Tribunal Electoral del Poder Judicial de la Federación: su contribución al desarrollo político democrático de México, México, TEPJF, 2003.

\section{CASOS CITADOS}

Amador vs. PVEM (2002): SUP-JDC-117/2001.

Albores (2006): SUP-JDC-1685/2006.

Alianza por Chiapas (2001): SUP-JRC-126/2001 y acumulados.

Arambula (2007): SUP-JDC-249/2007.

Coahuila (2007): AI-158/2007 y sus acumuladas.

Distrito Federal (2008): AI-158/2008 y sus acumuladas.

González (2003): SUP-JDC-341/2003.

Hernández y otros (2004): SUP-JDC-713/2004.

Luna (2006): SUP-JRC-394/2006.

Ruibal y otros (2006): SUP-JDC-8/2006. 